\title{
Relations between present relief on the border of lowlands and highlands and geological structures of the Paleozoic Platform - a case study from central Poland
}

\author{
Aleksander Szmidt, Lucyna Wachecka-Kotkowska \\ University of Lodz, Faculty of Geographical Sciences; ul. Narutowicza 88, 90-139 Łódź, Poland; \\ e-mail: aleksander.szmidt@geo.uni.lodz.pl,lucyna.wachecka@geo.uni.lodz.pl
}

(C) 2019 Authors. This is an open access publication, which can be used, distributed and reproduced in any medium according to the Creative Commons CC-BY 4.0 License requiring that the original work has been properly cited.

Received: 30 July 2018; accepted: 09 March 2019; first published online: 08 April 2019

\begin{abstract}
The article is an attempt to find relations between geology and the dynamics of the Mesozoic surface of the Łódź Synclinorium, the Radomsko Elevation and the Bełchatów Graben and the present relief on the border of the Polish Lowlands and Uplands in its central part. Fossil relief has been compared with the present one as related to the extent of the recession phases of the Saalian (Wartanian) ice-sheet. A significant convergence has been found between the Mesozoic surface plain and the main morphologic elements. The role of elevations and fossil valleys has been stressed as stable forms in the pre-Pleistocene and contemporary landscape. Also stressed has been the meaning of grabens and elevations enforcing longer stoppages of the Wartanian stadial of the Middle Polish Glaciations.
\end{abstract}

Keywords: Paleozoic platform, sub-Quaternary surface, relief inheritance, contemporary relief, central Poland

\section{INTRODUCTION}

The geological structure on the border of Polish Lowlands and Uplands in its central part for over a hundred years has been often discussed in periodicals and academic handbooks on the geology and geography of Poland (e.g. Passendorfer 1927, Lewiński 1928, Dylikowa 1973, Dadlez 1989, Kondracki 2011, etc.). The structure of the Łódź Synclinorium and adjacent areas has generally been discussed against a background of the Paleozoic Platform (Pożaryski 1971, Pożaryski \& Brochwicz-Lewiński 1979, Stupnicka 1989, Stupnicka \& Stempień-Sałek 2016), Radomsko Elevation (Euniewski 1947, Tokarski 1958, Baraniecka 1971, Czubla 1988, Żeleźniewicz et al. 2011), with especially the Bełchatów Graben (Ciuk 1980, Krzyszkowski 1992) being given a more detailed description.
The Quaternary cover and geomorphological forms in the studied area were fragmentally approached, with only the Late Saalian (Wartanian) ice-sheet being stressed in the evolution of the relief (Baraniecka 1971, Klatkowa 1972, Ziomek 1986, Krzemiński 1988, 1989, 1997, Kurkowski \& Popielski 1991, Brzeziński 1992, Rdzany 2009, Wachecka-Kotkowska 2015a). Nonetheless, the first serious remarks concerning preglacial series from Piotrków Trybunalski can be found in Lewiński (1928), and in Dylik (1948). True morphometric characteristics of the Piotrków Plain appeared in the second half of the $20^{\text {th }}$ century and concentrated on contemporary surface investigations as related to the substratum, but only regarding specific parts of the fossil forms (Ruszczyńska-Szenajch 1966, Baraniecka \& Sarnacka 1971, Krzemiński 1997, Wachecka-Kotkowska 2004, 2006, 2015a). 


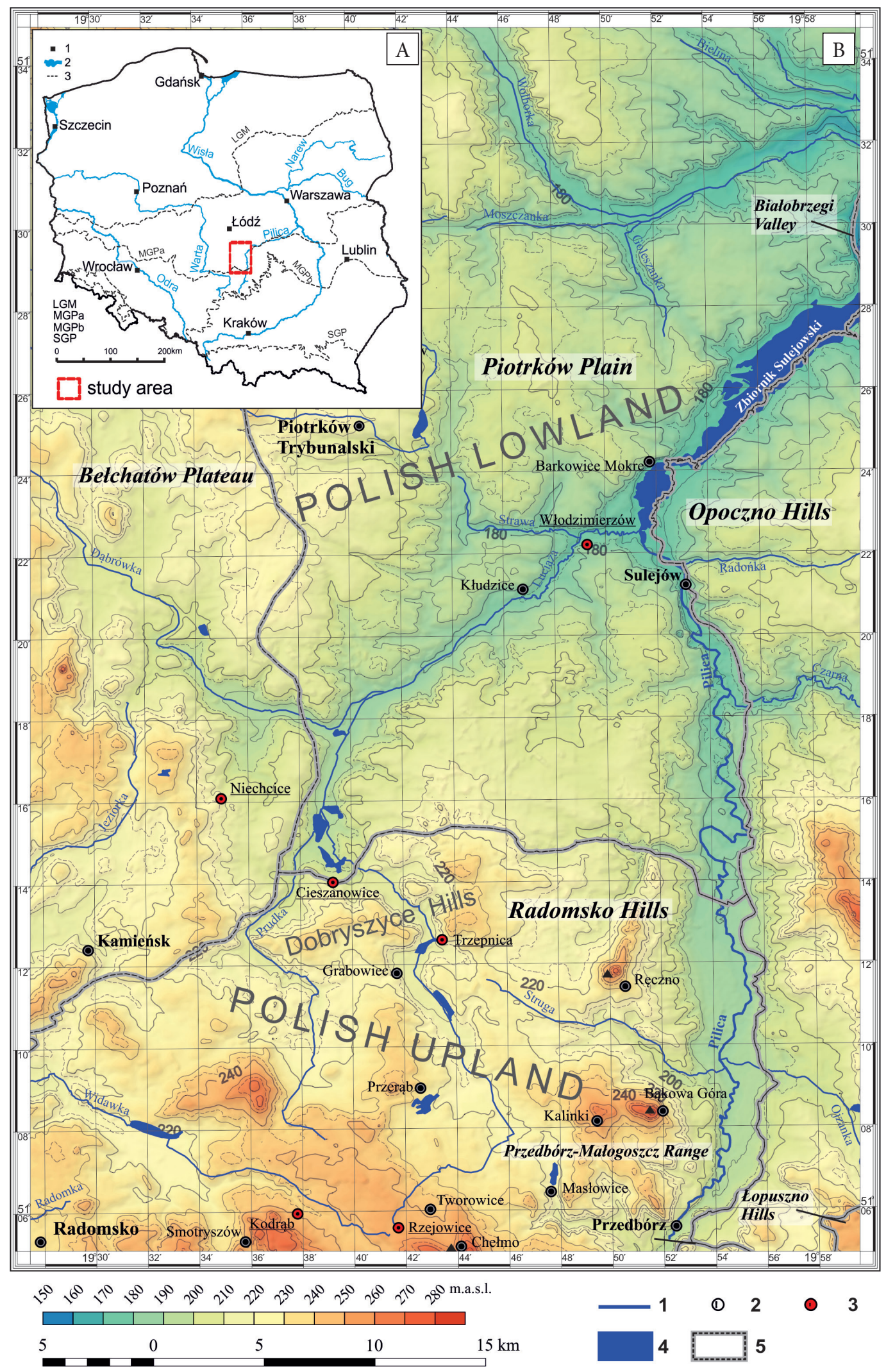

Fig. 1. Investigated area against hypsometry and physo-geographical division: A) 1 - cities, 2 - hydrography, 3 - limits of the Pleistocene ice-sheets, LGM - Last Glacial Maximum (Vistulian), MGPa - Middle Polish ice-sheet maximum (Late Saalian, Wartanian stadial), MGPb - Middle Polish ice-sheet maximum (Early Saalian, Odranian stadial), SGP - South Polish Glaciations (Elsterian); B) 1 - rivers, 2 - places, 3 - settlements (see in the text), 4 - reservoirs, 5 - mesoregions (after Solon et al. 2018) 
The discovery of lignite in the Bełchatów Graben and the analysis of deep prospecting drillings gave a significant impulse for further research (Baraniecka 1971, Baraniecka \& Sarnacka 1971, Ciuk 1980, Krzyszkowski 1992). The geological mapping as part of the Detailed Geological Map of Poland, scale of 1:50,000, which began in the 1960's, provided a lot of valuable data (Grzybowski 1968, Kwapisz 1983, Ziomek 1986, Wągrowski 1987, Kurkowski \& Popielski 1991, Brzeziński 1992).

To date, there have been no reflections in subject literature on the relation between the geological structure, the dynamics of the substratum and the contemporary relief of the area located in the Cretaceous zone in the southern edge of the Łódź Synclinorium as part of the Mesozoic Mid-Polish Trough. Paleogene and Neogene investigations have been carried out in the northern boundaries/ edges of the Uplands of Meta-Carpathian Arch while our investigations focus along the border between the Polish Lowlands and Uplands in its central part.

According to the physico-geographical division of Solon et al. (2018), the studied area is located on the edge of the province of the Central European Lowlands and the provinces of the Małopolska Upland (called also as Little Polish Upland) in the (Fig. 1). In the northern part of the area spreads the Piotrków Plain, as a mesoregion of the South Mazovian Hills. In the south it comprises the Radomsko Hills, belonging to the Przedbórz Upland.

In the borderland character of the area under investigation between the Polish Lowlands and Uplands and its relation to the tectonic and physico-geographical units, a convergence can be assumed between the contemporary relief and structure of the bedrock. Therefore, the influence of the impact of the structure and dynamics in the substratum on the Pleistocene and Holocene deposits, the development of morphology and the features of contemporary relief are the core of the considerations of this article. The aim of this work is to present the relationships between contemporary and fossil relief on the border of the Polish Lowlands and Uplands in its central part.

\section{GEOLOGICAL SETTINGS - GEOLOGICAL STRUCTURE AND SUB-PLEISTOCENE RELIEF}

All of the geological subunits are located on a Paleozoic Platform (Fig. 2) and it was on this that the Permian-Cretaceous Polish Basin originated. It is the system of epicontinental depositional basins of Western and Central Europe. Its axial part (the so-called Mid-Polish Trough), characterized by the thickest Permo-Mesozoic sedimentary cover, developed above the Teisseyre-Tornquist Zone, lithospheric-scale boundary separating the East European Craton and the Paleozoic Platform. The Polish Basin was inverted in Late Cretaceous-Paleocene times (Żeleźniewicz et al. 2011, Stupnicka \& Stempień-Sałek 2015).

In the investigated area, on the border of the Polish Lowlands and Uplands between Piotrków Trybunalski and Przedbórz, the oldest formation appearing on the sub-Cenozoic surface are the Triassic and Lower Jurassic sediments in the south (Fig. 2). They lie within the Radomsko Elevation (Pożaryski 1971), called the Przedbórz Bridge (Kurkowski \& Popielski 1991), the Kodrąb Elevation (Samsonowicz 1937) or the Przedbórz Elevation (Stupnicka \& Stempień-Sałek 2015), separating the Łódź from the Miechów Synclinoriums. The Jurassic rocks are exposed within the Smotryszów and Chełmno Anticlines and in the east, on the slope of the Kuyavian-Pomeranian Anticlinorium - in the Sulejów and Kalinki Anticlines. The Smotryszów and Chełmno Anticlines, with the NW-SE axes, formed along the right-handed, clockwise, deflection which was created during the Laramian orogenetic phase, on the extension of the Paleozoic Holy Cross Mountain fault with the direction of WNW-ESE.

The largest sub-Cenozoic surface make the Jurassic deposits of the Łódź Synclinorium: silts and mudstones with siderites, sandstones, geses, limestones and marls. Those sediments appear in many units of a lower order within the area, the Kamieńsk Anticline, the Parzno-Kraszewice, the Masłowice and the Bąkowa Góra synclines as well as in the Bełchatów Anticline and the Piotrków-Smyków Syncline. 
Faults in the Mesozoic substratum run NE-SW, over the Niechcice-Sulejów line and perpendicular to the axis of the Łódź Synclinorium and the NW-SE deflection, parallel to the bedrock structures. They are associated with the Laramian orogenetic phase. On the border between the Łódź Synclinorium and the Kuyavian-Pomeranian Anticlinorium Brzeziński (1992) we found a number of faults generations - west of Sulejów, the Asturian phase types related to NW-SE course (e.g. Kłudzice-Piotrków). Other faults connected with the Laramian orogenetic phase and division of the trough and syncline into blocks, are consistent with the post-Cretaceous dislocation (Kobyłecki 1948) and located along the present lower Luciąża and Pilica River valleys near Sulejów, SW-NE and the fault along the Strawa River on the course of W-E.

The Łódź Synclinorium is transversely cut by the Bełchatów Graben (Krzyszkowski 1992) associated with the Sava phase of the Alpine orogeny (Ciuk 1980). Paleogene and Neogene deposits also take their part in the Quaternary substratum. The sedimentation of those forms took place mostly within the secondary depressions in the Mesozoic surface and, in the central part of the area, Paleogene rocks were found. A complex of Neogene mud-sand-silty rocks with lignite deposits appears in deeper sinks of the Piotrków-Smyków Syncline. Lignite-bearing Neogene deposits lie mostly in the Bełchatów Graben.

A significant feature of the sub-Quaternary surface relief is its diversity in inselbergs of about 260$330 \mathrm{~m}$ a.s.l. in the south of the study area, which follows in its course to the north into the plain (Fig. 2), cut by the Niechcice and Włodzimierzów fossil valleys (Ruszczyńska-Szenajch 1966) and gently descending to the center into the valley between Piotrków and Barkowice Mokre near Sulejów (120-140 m a.s.l.).

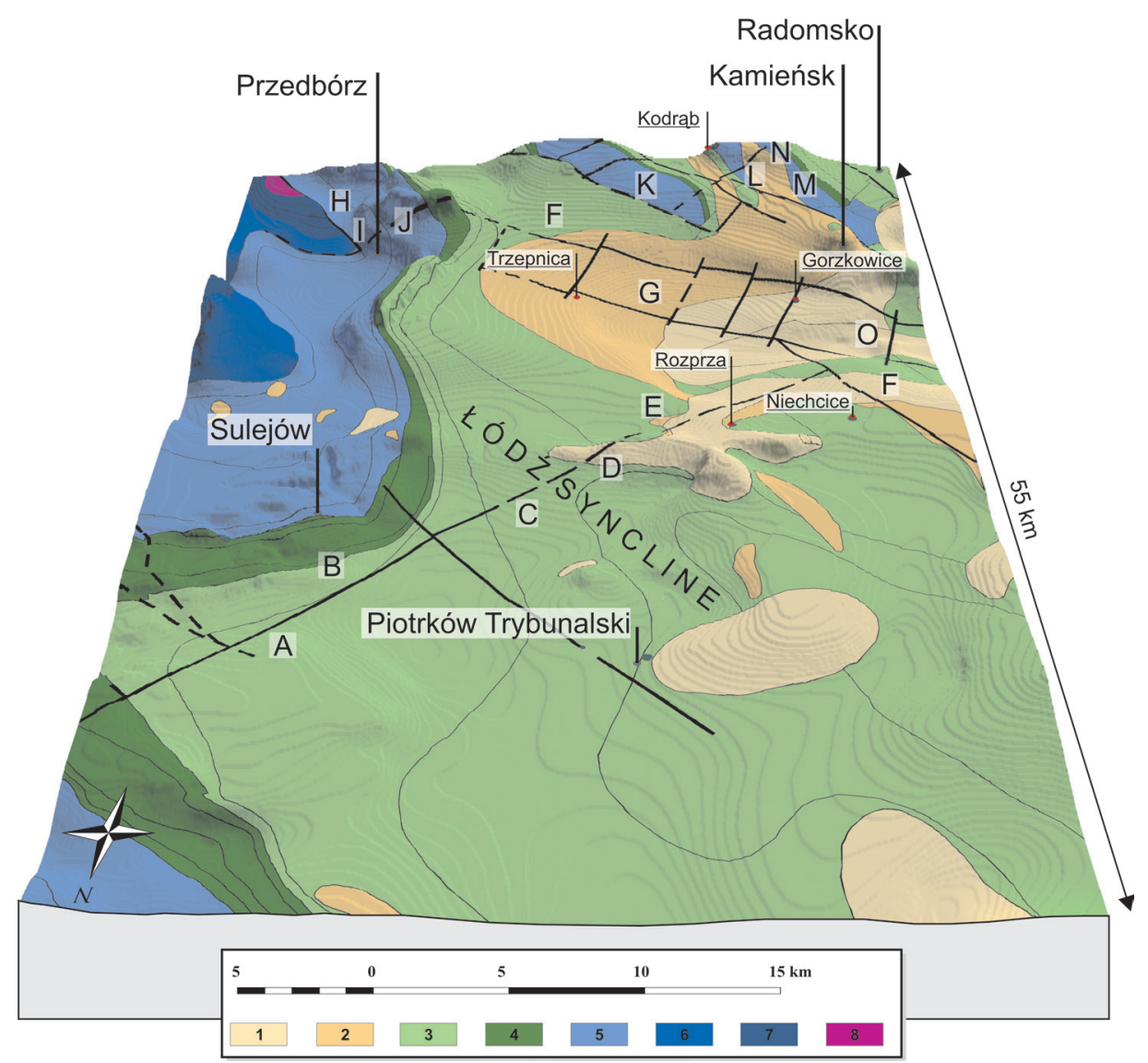

Fig. 2. Geology of pre-Quaternary surface and tectonic subunits of the Łódź Synclinorium: 1 - M/Ng (Miocene / Neogene), 2 - PAL (Paleogene), 3 - Cr3 (Upper Cretaceous), 4 - Cr14 (Lower Cretaceous), 5 - J3 (Upper Jurassic), 6 - J2 (Middle Jurassic), 7 - J1 (Lower Jurassic), 8 - T (Triassic); A - Sulejów Antycline; B - Włodzimierzów fossil valley; C - Piotrków-Smyków Syncline; D - Bełchatów Antycline; E - Niechcie Fossil valley; F - Parzno-Kraszewice Syncline; G - Bełchatów Graben; H - Przedbórz-Małogoszcz Monoclinal Range; I - Bąkowa Hill Syncline; J - Kalinki Antycline; K - Chełmo Antycline; L - Zapolice Syncline; $M$ - Smotryszów Antycline; N - Radomsko Elevation; O - Grzymalina fossil valley 
The relief of the sub-Pleistocene surface is diversified by means of a range of mesoforms and microforms. The largest and dominant convex mesoforms of a latitudinal course is, in the south, the transverse Radomsko Elevation, manifesting itself as an elevation of the Mesozoic plateau with a height of $40-80 \mathrm{~m}$ a.s.l. Monadnocks on average 170-180 $\mathrm{m}$ a.s.l. varied in the remaining area. Elevation humps are cut out by marked concave valley-type forms associated with the occurrence of fault zones, perpendicular or parallel to the axis of the Łódź Synclinorium. They make the Niechcice and Włodzimierzów (Ruszczyńska-Szenajch 1966), Masłowice (Lindner 1971) and Grzymalina (Baraniecka \& Sarnacka 1971) fossil valleys running perpendicular or parallel to the axis of the syncline. The depth of the valleys varies from 30 to $100 \mathrm{~m}$. The ordinal bottoms of fossil valleys reach the value of 90-130 m a.s.l. Relative height differences upon the sub-Quaternary surface exceed $200 \mathrm{~m}$ over a distance of only $30 \mathrm{~km}$ (Fig. 2).

Substratum microforms, both convex and concave, play a lesser part in the diversity of the sub-Pleistocene relief. Monadnocks (inselbergs) of an erosional-denudation character in all the area are mostly often fossil mogoths, e.g. in the vicinity of Witów, $7 \mathrm{~km}$ SE of Piotrków. Concave microforms of different origin also diversify the area. They make small shallow holes, valleys or karst funnels (e.g. in the vicinity of Rzejowice between Przedbórz and Radomsko), filled with Pleistocene sediments (Wachecka-Kotkowska 2004, 2015a).

\section{MATERIAL AND METHODS}

To this aim, archival data of drillings in the Polish Geological Institute were first collected from the local commune administrations and Piotrków Trybunalski regional agencies. The most important and basic materials used to determine the relationship between contemporary and fossil relief were obtained from the Detailed Geological Maps of Poland of a scale of 1: 50,000 and its Explanations.

GIS (Geographic Information System), raster and vector graphics processing software were used to acquire and process data. In the case of GIS software, ESRI ArcGIS 10.5, Golden Software Surfer 14, Quantum GIS and SAGA GIS were used.
CorelDraw X7 and GIMP 2.8 software were used for graphics, e.g. 2.5 or 3D dimensional maps and blockdiagrams. The authors used the above equipment to present the results in all of the figures in this article.

In the next stage, GIS tools were used to visualize the geological data and the present relief. The best source of data for determining fossil surfaces are geophysical measurements, in particular georadar measurements. The second source of the data was obtained from borehole profiles.

In order to obtain an image of the sub-Quaternary surface, sketches from in the 1: 100,000 scale were taken into account, attached to the Detailed Geological Map of Poland (DGMP), scale 1: 500,000 and Geological Map of Poland 1: 200,000, ed. B (without Quaternary cover). The list of materials showed that the entire research area includes a total of 12 sheets of DGMP which, importantly, were made over a long period of time, with various guidelines for geological mapping. This means that the morphometric content presented there is inconsistent and thus the authors decided to use smaller-scale maps. The obtained image, based only on the Geological Map of Poland (B edition) on a scale of 1:200,000, may constitute a considerable simplification but it is the most coherent in terms of relief (morphology), lithology and the period of elaboration.

Geological maps were issued using the traditional technique (printing), therefore, after scanning them in a resolution of $600 \times 600 \mathrm{dpi}$, they were given a spatial reference. In the next step, a manual digitization of the morphometric situation of the sub-Quaternary surface and lithology of this surface was made.

For the contemporary area, the most accurate morphometric information currently comes from laser scanning data (LiDAR). In all of these cases, the methods and measurement results can be efficiently applied to small research areas. During research on the fossil surfaces of large areas, it is difficult to perform measurements with the above-mentioned techniques, and even impossible with the currently available technology. For the contemporary area, in the case of LiDAR data, so-called "noise" data, and the model itself may require strong generalization for further processing. 
For the contemporary area, the Digital Terrain Model was made available by CODGiK's (Polish Center for Cartographic and Surveying Documentation) with a resolution of at least 25 meters. In this model, the remaining artefacts were removed as a result of interpolation and, for the purposes of cartographic presentation, the model was smoothed by the local polynomial method.

The source materials were published in various geodetic coordinate systems and therefore needed to be processed into a common spatial reference. Due to the location of the research area in central Poland, it was decided to use the 1992 one-zone geodetic coordinate system.

The raster data for fossil and contemporary surfaces obtained were reinterpolated to obtain the same horizontal resolution and location of nodal points of raster cells. This process was aimed at normalizing data for other morphometric analyzes and studies. The above procedures allowed us to make all of the figures (Figs. 1-5) and to interpret relation basement-contemporary relief.

\section{MORPHOLOGIC DEVELOPMENT OF THE AREA IN THE QUATERNARY}

Quaternary deposits and deposits cover 95\% of the area between Piotrków Trybunalski and Przedbórz (Fig. 3). They are not only found in the south and south-east. Generally, the Quaternary thickness grows from zero in the south to $60-$ $70 \mathrm{~m}$ in the north, except in the central belt made by the Grzymalina and Niechcice fossil valleys. The largest thicknesses are recorded only in the Bełchatów Graben (103 m). Such significant values of thickness except of the elevation zone result from the subsidence of the area (Krzyszkowski 1992), the relative "isolation" from destructive processes (Baraniecka \& Sarnacka 1971) and, perhaps, recurring tectonic activity (Baraniecka 1975, Kurkowski \& Popielski 1991) during the Pilica interstadial (Bełchatów phase according to Krzyszkowski 1992).

The older Pleistocene deposits are represented by preserved sediments in remnant valleys, e.g. the Niechcice fossil valley (Ruszczyńska-Szenajch 1966) - so-called preglacial series, covered with sediments of the South Polish Glaciation (Elsterian; in Polish: San 1 San 2). In the Mazovian Interglacial (Holsteinian, MIS 15-9 (Marine Isotope Stages)), the valley forms were first deepened (Mazovian tectonic phase according to Baraniecka (1975)), and then filled with fluvial and lacustrine sediments with a thickness of several dozen meters (Sobolewska 1952, Baraniecka \& Sarnacka 1971, Różycki 1972). In the north-western part on the axis of the Niechcice old-Quaternary fossil valley, Ruszczyńska-Szenajch (1966) described a 34-meter sand-gravel series. In a similar situation - along the post-Cretaceous fault (Kobyłecki 1948) - the same author documented a fragment of the interglacial valley at Włodzimierzow $(3 \mathrm{~km}$ above the mouth of Luciąża to the Pilica River), filled with a thirty-meter series of river-flooding.

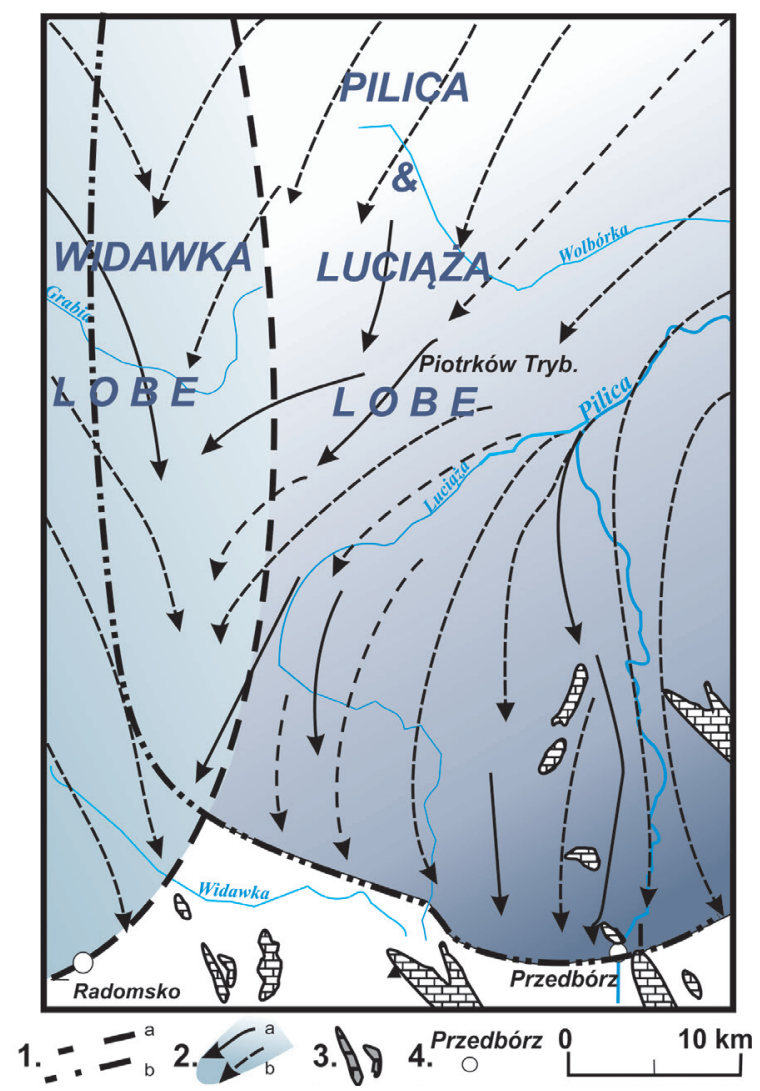

Fig. 3. Directions of ice flow in the Wartanian (Saalian) marginal zone of the ice sheet (acc. to Wachecka-Kotkowska 2015b, changed): 1 - lobes limit: $a$ - Widawka, b - Pilica \& Luciaża (as S part of the Rawka Lobe); 2 - directions of ice inflow: a - determined on the basis of the investigations (see: Wachecka-Kotkowska 2015a, 2015b), b - presumed; 3 - nunatak (hills built of Mesozoic rock); 4 - main towns 
The Saalian cycle (Odranian, MIS6) starts with lower-silt sandstones and gravels, with an average thickness of $8 \mathrm{~m}$. They also lie against fluvial sediments originating from the Mazovian Interglacial (Holsteinian). They are covered with lower clay and till from the Odranian maximum stadial, which occurs on the surface only in the south, near the Chełmno Hill (323 m a.s.1.).

In the south of the area, the Wartanian ice sheet advanced from southern Sweden (Czubla 2015, Wachecka-Kotkowska 2015a, b) and reached an elevation of $250 \mathrm{~m}$ a.s.l. in the zone of Radomsko Elevation faults and the Chełmo Hill, and crossed the Przedbórz-Małogoszcz Range at Przedbórz (Wachecka-Kotkowska 2013). It was represented by the eastern, Pilica-Luciąża lobe (as the southern part of the Rawka lobe) that advanced to the Kamieńsk-Kodrąb-Rzejowice-Przedbórz line (Fig. 3). During the next recession, the Wartanian stadial, a fairly wide zone of stagnation and deglaciation was formed (Lindner 1970, 1977), which was based on the Radomsko Elevation, because the bolt was a serious obstacle to the greater spread of the ice-sheet (Wachecka-Kotkowska 2004, 2006). The glacimarginal forms created during this stadial were "glued" to the northern slope of the Mesozoic hump.

The last glacial event that affected the shaping of the relief of the studied area was the transgression of the Wartanian ice sheet. In the internal surface of the central and northern parts of the research area, the last Wartanian phase of recession was the most significant. Upper till and fluvioglacial sediments created the surface of the morainic plateau and partly the front-moraine hills of the Piotrków Plain. The course of the hills is generally consistent with the direction of the Bełchatów graben. During the Saalian glaciation, the elevation was subject to an uplift during the Bełchatów phase according to Krzyszkowski (1992) and its foreground to a decline (Wachecka-Kotkowska 2004, 2006, 2015a).

The first, the outermost sequence of kames and dead (terminal) moraines forms, occurring in the area of research, located to the west of Niechcice, is consistent with the course of the Niechcice fossil valley (Wachecka-Kotkowska 2004, 2015a). At the end of the Saalian Glaciation (Wartanian) and in the Eemian Interglacial (MIS5e), the river network began to form in the studied area, but its image differed significantly from the contemporary one. Only in periglacial conditions, during the Vistulian (Weichselian), especially the LGM (Last Glacial Maximum, MIS2), precisely at the beginning of the middle Pleniglacial (50-38 ka BP, MIS3) the morainic Dobryszyce Hills were cut out, creating a valley network similar to the contemporary one (Wachecka-Kotkowska 2004). In the Vistulian Glaciation, the valley forms were filled with sands and silty-sands. There were also aeolian processes that created dunes and sandy aeolian covers. The youngest, Holocene mineral-organic deposits mainly built the bottoms of modern valleys.

In the Holocene, subsidence appeared in the remnant valleys on the line of the old faults in the vicinity of Sulejów and Grabowiec (S of Trzepnica) within the Bełchatów Graben. The elevations were uplifted during the late-Quaternary tectonic phase according to Krzyszkowski (1992).

\section{FEATURES OF CONTEMPORARY RELIEF}

The current relief of the studied area was influenced by Neogene and Pleistocene morphogenesis. The domed culminations surrounding the valley from the south - Chełmo Hill (323 m a.s.l.) - and from the south-east - Bąkowa Góra (279 m a.s.l.) near Kalinki and Czartoryja (267 m a.s.l.) near Ręczno, connected with outcrops of the older subsoil, pass below the peaks in several horizons (250-270 m a.s.l.) of the Paleogene-Neogene denudation (Kwapisz 1983). Those horizons are seen on the northern slope of the Chełmo Hill between Rzejowice, Tworowice and Chełmo. Manikowska (2000) believes that the area within the Chełmo Hill should be associated with the Pliocene phase of denudation, after the activation of vertical movements in the Styrian phase (Middle Miocene), which rejuvenated the relief in the whole belt of the Polish Upland and the intensive erosion of weathering covers.

Forms of the Neogene structural relief within the Radomsko Hills pass gently towards the north in the denuded Pleistocene plain (Piotrków Plain) (Fig. 4). The largest areas of the described area are occupied by the upland areas, mainly made of glacial and water-glacial deposits originating from the Middle Poland Glaciations (Lindner et al. 2013). 

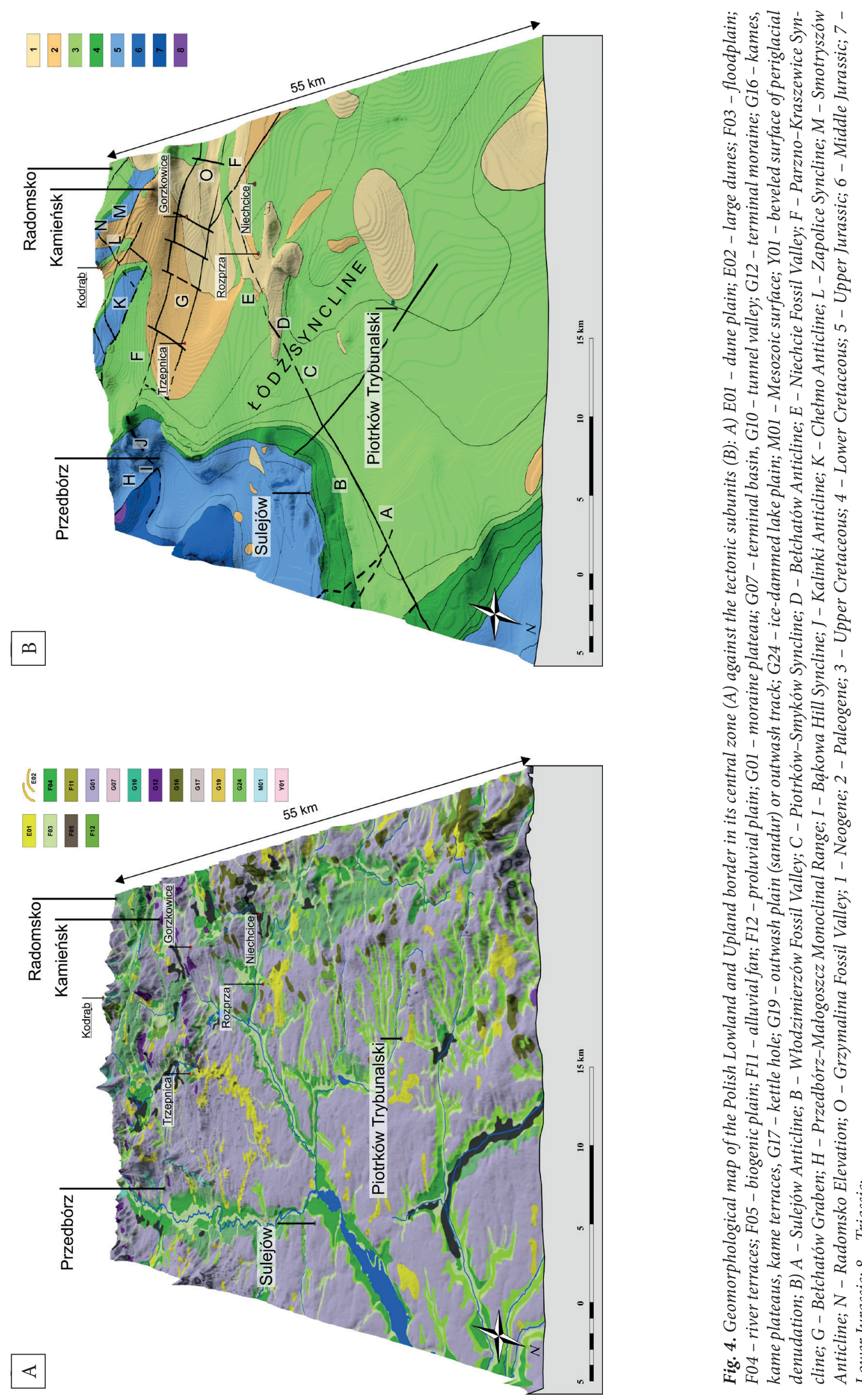

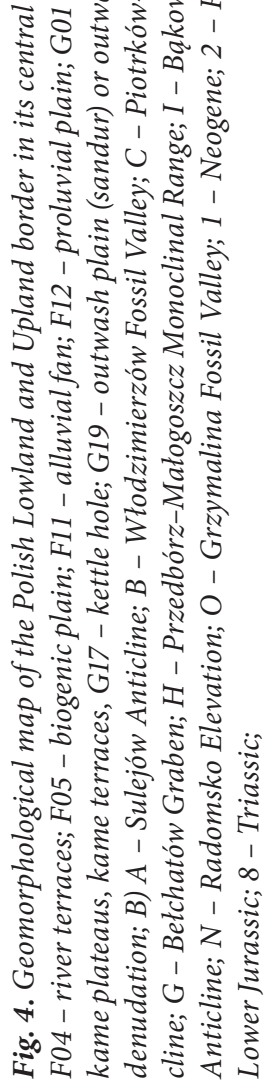


Within the Radomsko Hills in the south, the upland is located at an altitude of $200-240 \mathrm{~m}$ a.s.l. and denotes the most vivid relief (Fig. 4). Towards the north, towards Piotrków Trybunalski and Sulejów, these surfaces are becoming more and more compact, flat (inclinations up to $1.5^{\circ}$ ) and the monotonous Piotrków Plain with 180-190 m elevations, diversified by the morainic hills. The whole area underwent strong transformations in periglacial climate conditions during the Vistulian glaciation (LGM).

Glacial relief is dominant in the present relief (Wachecka-Kotkowska 2015a). We can distinguish three stages of their development, pre-Odranian, Odranian and Wartanian and six detailed substages:

A. Period before ice-sheet advance, accompanied by development of outwash plains and periglacial structures within them.

B. Advance of the Wartanian ice sheet to the maximum limit of the ice lobe, reaching the northern slopes of the uplands to an elevation of $250 \mathrm{~m}$ a.s.l.

C. Stagnation of the Wartanian ice sheet along the Radomsko-Przedbórz Hills line, and the onset of deglaciation of the ice lobe; confluence of the Widawki lobe and the Rawka, and Pilica and Luciąża lobes (Fig. 3).

D. Recession and stagnation of the ice sheet along the Gorzkowice-Trzepnica-Ręczno line.

E. End of deglaciation of the Pilica and Luciąża lobe.

F. Postgalcial, post-Wartanian last stage of the development is relief transformation during Vistulian and Holocene.

The biggest concave form, cutting the plateau and the next series of hills is the valley of Luciąża (Wachecka-Kotkowska 2004), connected with the Pilica valley of $\mathrm{N}$ from Sulejów. It takes its origin on the facade of Radomsko Elevation at the foot of the Chelmo Hill; ends at the slope of the Kuyavian-Pomeranian Anticlinorium. Apart from the Luciąża valley, there are other smaller concave forms on the plateau starting from melt bowls, gutters and valleys of fluvioglacial waters, denudational valleys, deflation basins (Krysiak 1999), valleys of side tributaries - Prudka, Bogdanówka, Strawa, Rakówka and other unnamed watercourses on peat plains in various hollows of the area.

\section{RELATIONSHIPS BETWEEN CONTEMPORARY RELIEF AND SUB-CENOZOIC BASEMENT}

The analysis of the relationships between the present-day relief and the substratum relief (Wachecka-Kotkowska 2006, Godlewska \& Terpiłowski 2012) allowed to indicate its role in the paleogeographic development (Wachecka-Kotkowska 2015a). A sequence of events throughout the Pleistocene, such as the glaciation and deglaciation processes, was controlled by the sub-Quaternary surface (Fig. 5). Four macroforms were identified in the basement, which affected the glaciation and deglaciation of the study area. In the south, (northern part of Polish Uplands), between Radomsko and Przedbórz, there is a transverse elevation of the substratum (Radomsko Elevation). In the west, between Radomsko and Łódź, extends a longitudinal elevation with relief variations, which is the eastern part of the Cretaceous Łódź Synclinorium "peninsula". In the eastern, central and northern parts of the area, the basement is composed of depression zones that belong to the south - western part of the Mazovian Basin of the Middle Polish Depression. In the central part, the Cretaceous Łódź Synclinorium is dissected by the Kleszczów Graben (Wachecka-Kotkowska 2004). Figure 6 is a graphical summary of the relationships between the glacial relief and the substratum.

The analysis of the geological structure and the Quaternary surface of the studied area, in reference to the development of the Quaternary cover and the nature of the relief, shows that there is a general convergence of the main morphological elements with the structure of the Mesozoic bedrock.

The background for the formation of contemporary relief were tectonic phenomena modified in the Quaternary by the influx of ice masses, followed by the disintegration of the South Polish (Elsterian) and Middle Polish (Saalian) Glaciations, which in turn influenced the river network assumptions.

Tectonic activity during Quaternary (Mazovian and Bełchatów phases) of an elevating character in the south, within the elevation, resulted in the removal of older Quaternary sediments, hence there are no traces of assumptions, e.g. old valleys. The exception is the fossil valley from the Masovian Interglacial NW from Przedbórz. 

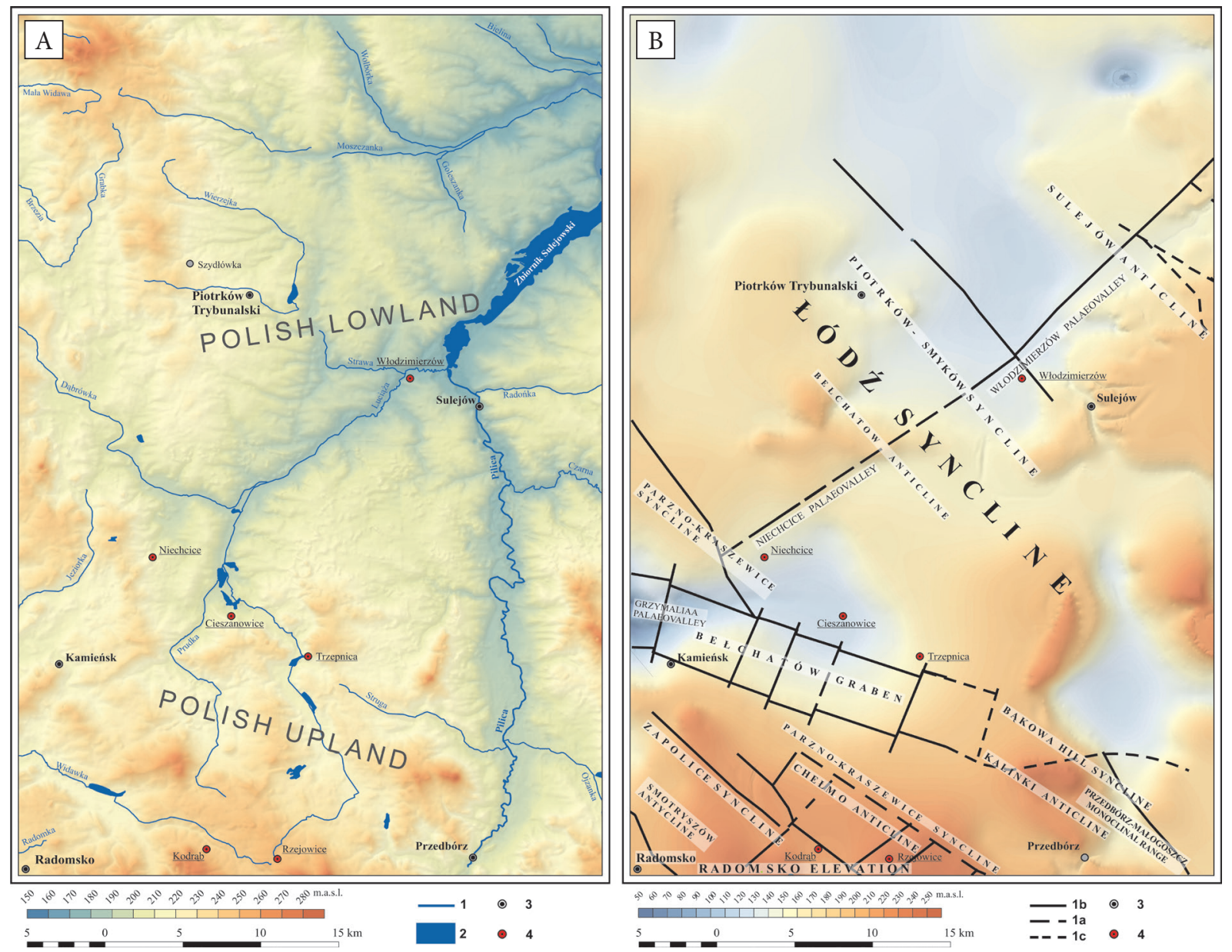

Fig. 5. Visualization of the present relief ( $A-3 D$ model) against the fossil, sub-Quaternary surface $(B)$ in the investigated area: A) 1 -rivers; 2 - reservoirs; 3 - towns; 4 - main settlements (see in the text); B) 1 -faults: $a$ - reliable; $b$ - uncertain; $c$ - probable; 3 - towns; 4 - main settlements (see in the text)

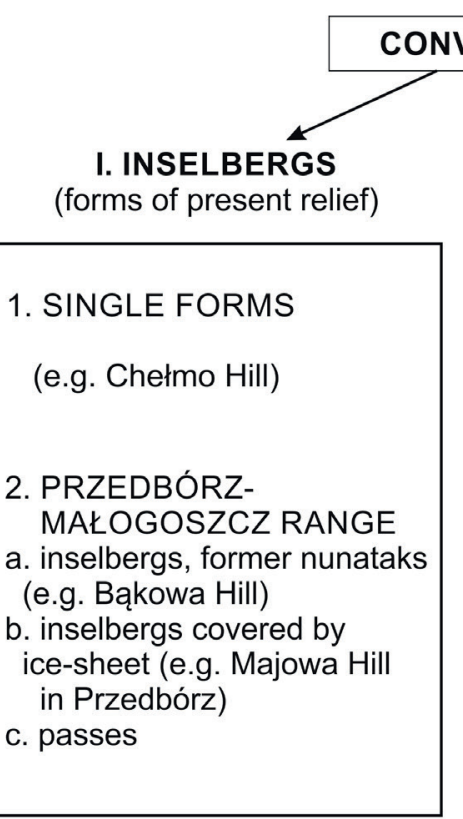

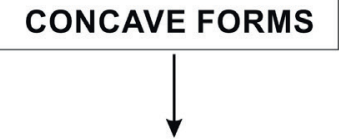

III. BASINS

(uplift of basement with cove a Pleistocene sediments (0-20 m. thick))

1. TRANSVERSAL

a. Kodrąb Elevation

b. southern faults system

of the Bełchatów Graben

c. local elevation

2. LOGNITUDINAL

a. Łódź Hump divided the Masovian and Greater Poland Neogene depresions

b. local

e.g. Chełmo Hill range

\section{KARST FORMS}

(e.g. funnels)

2. DEPRESIONS

within syncline

a. Piotrków-Smyków S.

3. LOCAL HOLES among inselbergs

\section{BEŁCHATÓW GRABEN}

5. FOSSIL VALLEYS

a. Niechcice Valley

b. Włodzimierzów V.

c. Grzymalina V.

d. Masłowice $V$.

Fig. 6. Summary of present and fossil relief relation (acc. to Wachecka-Kotkowska 2015a, changed) 
The Radomsko Elevation (or Radomsko Hills in the morphological sense) constituted an obstacle to the spread of the Wartanian ice sheet (Fig. 4). It had an oscillatory character of transgression and decay (Fig. 3). In the vicinity of the Przedbórz marginal, proglacial and front-moraine valleys were formed. The decline of the ice sheet depended mainly on the configuration of the Mesozoic substrate within the framework of folding and skeleton elevations. First, there was a decrease in the thickness of the ice sheet, and then there were several changes and the break-up of the ice sheet into a series of dead ice cubes. One of the transitions was connected with the haughtiness of the older subsoil in the elevation area (in the SW-NE direction) - it was found between the disappearing ice and the slopes of the Mesozoic hills; the other one transversally to the elevation, on the extension of the Chełmno ridge (Wachecka-Kotkowska 2013). In the south-west, near Rzejowice-Kodrąb, the expanding transitions were flooded with fluvioglacial sediments that built kames and the outwash fluvioglacial plain referring to the outflow route of the upper pra-Widawka River system (Fig. 4). Secondary transversal elevations found on the Przerab-Chełmo Hill line affected the deglaciation, the asymmetry in the organization of the outflow of waters, and this in turn was important in the subsequent formation of the initial upper sections of the Luciąża and Widawka River valleys.

The Bełchatów Graben, including the Grzymała valley, was filled with a Quaternary complex was at the top covered by glacial deposit and formed the morainic Dobryszyce Hills, spread along the Trzepnica-Cieszanowice line. To the north, the Piotrków Plain is a glacial plateau of sandstone surfaces cut by marginal valleys (Fig. 4). There was a deep depression modeled by meltwater in the inner zone of the Saalian ice-sheet, which was established on the line of the ground fault, in the section inherited from the valley from the large interglacial and perhaps from the preglacial (Wachecka-Kotkowska 2015a). Nowadays, the valley of the lower Luciazza duplicates the pre-Quaternary relief - from the Niechcice valley (eastern part) to the fossil Włodzimierzów valley and further to pra-Pilica valley (Fig. 3).
The periods of subsidence, i.e. the accumulation phases in the valleys, were separated by periods of tectonic calm, which were expressed in the erosion phases. A small width, e.g. a section of the Luciąża estuary ( $\mathrm{N}$ part of the area), of a breakthrough character, forced width of the meander belt, could be explained by the alternating uplifting and lowering of the area along the post-Cretaceous fault. In fairly wide sections of the valleys, where a free meandering belt could develop, the neo-tectonic processes in the Holocene had to be less intense.

Similarly to Bełchatów Graben with the Grzymalina fossil valley in it, the western part of the Niechcice fossil valley was filled with glacial and interglacial series. Here, as in the graben, the existing reduction in the ground forced a longer standstill of the glacier in its outer zone, followed by the disintegration of the glacial forms on the longitudinal hump.

\section{DISCUSSION}

The present glacial upland surface at the borderland of the uplands and the periglacial lowlands, was probably formed during the Wartanian Stadial of the Middle Polish (Saalian) Glaciations (145-135 ka BP) (Turkowska 2006, Wachecka-Kotkowska, 2015a). Thus, the study area is part of the Wartanian morphogenetic zone (Fig. 4). The determination of the age of the glacial plateau in the south-eastern part of the Łódź region and any verification of the Wartanian ice-sheet extent have a pan-regional significance, complementing the general picture of the Middle Polish Glaciations (Saalian) outlined by Lambeck et al. (2006), Ehlers and Gibbard (2007), Rdzany (2009), Colleoni et al. (2011) and Lindner et al. (2013). In these publications, the southern part (i.e. the northern slopes of the Central Polish Uplands) is not regarded as Wartanian in origin but rather older, i.e. Odranian.

Polygenesis, complexity and inheritance of the relief were also discussed, thereby complementing its characteristics in terms of the theory of relief development. The asymmetry in the distribution of the glacial forms should be associated with the heterogeneity of the construction of the 
Radomsko Elevation, which was emphasized by Czubla (1988). The concept of relief polygenesis in central Poland, proposed by Dylik (1953) and understood as the overlap of morphogenesis of the periglacial zone and the moderate climate zone of the glacial morphogenesis of this zone, has been fully confirmed in the study area. The issue of relief polygenesis and inheritance are undoubtedly essential for the study area located in a transitional zone between the Polish Uplands and Lowlands, as well as within the ice-marginal zone sensu stricto, which was shaped by ice lobes advancing from different directions and strictly aligned with the local bedrock features. Even though the research achievement refers to a regional aspect, it is important because it is a starting point for considerations on the polygenesis and inheritance of the relief in the southern part of the periglacial lowlands of central Poland. This confirms the thesis about the substratum permanency and relief inheritance (Dadlez 2001, Turkowska 2006, Wachecka-Kotkowska 2015a).

\section{CONCLUSIONS}

The elevations (the transverse Radomsko Elevation and the longitudinal elevation in the Łódź hump) inhibited the inflow of ice mass, which resulted in the formation a few ice-marginal zones (in the south and west). Valley depressions, including the middle pra-Pilica and the lower pra-Luciąża valleys (in the north), facilitated the spreading of ice masses. They were pathways for meltwater to flow inside and outside the ice sheet during deglaciation.

In the south, the elevation of the Quaternary Basin is reflected in the present morphology as tan area of upland humps - the Radomsko Hills, which constituted a serious obstacle to the spread of the Saalian (Wartanian) ice-sheet. Due to the transverse elevation, the ice streams had to stop and stay longer and this is evident from the presence of front-moraine hills to the north of the Przedbórz-Rzejowice line and the outwash fluvioglacial plain from Rzejowice.

Noteworthy is the stability of the linear forms associated with fault zones. Most of today's valleys have pre-Holocene foundations. In the Quaternary, the valley forms occurring on the Piotrków
Plain and in the north-eastern part of the Radomsko Hills were a place of Wartanian ice-mass stagnation. Here, the accumulation of river-glacial sediments took place; in the interglacial the river network was renewed, as seen in the fluvial series, estimated at ca. $30 \mathrm{~m}$ in thickness (the Włodzimierzów valley and the eastern part of the Niechcice valley).

Linear forms found in the basement (e.g. the western part of the Niechcice and Grzymalina fossil valleys) also forced a longer stop of the Saalian (Wartanian) ice-sheet. These forms are superimposed by morainic hills (Dobryszyce Hills), which determine the ranges of subsequent recessionary phases of the Wartanian ice-sheet.

Small bends and humps of the sub-Cenozoic substratum were of no importance for the development of the relief of the Piotrków Plain and the Radomsko Hills.

\section{REFERENCES}

Baraniecka M.D., 1971. Dorzecze Widawki na tle obszaru marginalnego stadiału mazowiecko-podlaskiego (Warty) w Polsce. Biuletyn Instytutu Geologicznego, 254, 11-36.

Baraniecka M.D., 1975. Zależności wykształcenia osadów czwartorzędowych od struktur i dynamiki podłoża w środkowej części Niżu Polskiego. Biuletyn Instytutu Geologicznego, 288, 5-97.

Baraniecka M.D. \& Sarnacka Z., 1971. Stratygrafia czwartorzędu i paleogeografia dorzecza Widawki. Biuletyn Instytutu Geologicznego, 254, 157-269.

Brzeziński H., 1992. Objaśnienia do Szczegółowej mapy geologicznej Polski 1:50 000: arkusz Sulejów. Państwowy Instytut Geologiczny, Warszawa.

Ciuk E., 1980. Tektonika rowu Kleszczowa i jej wpływ na warunki powstania złoża węgla brunatnego. [in:] Barczyk W. (red.), Przewodnik LII Zjazdu Polskiego Towarzystwo Geologicznego: Bełchatów, 11-14 września 1980: praca zbiorowa, Wydawnictwa Geologiczne, Warszawa, 38-55.

Colleoni F., Krinner G., Jakobsson M., Masina S. \& Peyaud V., 2011. The sensitivity of the Late Saalian (140 ka) and LGM (21 ka) Eurasian ice sheets to sea surface conditions. Climate Dynamics, 37, 3, 531-553.

Dadlez R., 1989. Epikontynentalne baseny permu i mezozoiku w Polsce. Kwartalnik Geologiczny, 33, 2, 175-198.

Dadlez R., 2001. Przekroje geologiczne przez bruzdę śródpolska 1:200,000. Państwowy Instytut Geologiczny, Warszawa.

Dylik J., 1948. Ukształtowanie powierzchni $i$ podział podłódzkiego obszaru. Acta Geographica Universitatis Lodziensis, 1, Łódzkie Towarzystwo Naukowe, Łódź.

Dylik J., 1953. O peryglacjalnym charakterze rzeźby środkowej Polski. Acta Geographica Universitatis Lodziensis, 4, Łódzkie Towarzystwo Naukowe, Łódź. 
Dylikowa A., 1973. Geografia Polski. Krainy geograficzne. Państwowe Zakłady Wydawnictw Szkolnych, Warszawa.

Czubla P., 1988. Tektonika elewacji radomszczańskiej na podstawie metod mezostrukturalnych. Przegląd Geologiczny, 10, 560-566.

Czubla P., 2015. Eratyki fennoskandzkie w osadach glacjalnych Polski i ich znaczenie badawcze. Wydawnictwo Uniwersytetu Łódzkiego, Łódź.

Ehlers J. \& Gibbard P.L., 2007. The extent and chronology of Cenozoic global glaciation. Quaternary International, 164-165, 6-20.

Godlewska A. \& Terpiłowski S., 2012. Transverse supraglacially-derived crevasse infillings in a Pleistocene ice sheet margin zone (eastern Poland): genesis and sedimentary record. Geomorphology, 161-162, 73-81.

Grzybowski K., 1968. Objaśnienia do Szczegółowej mapy geologicznej Polski w skali 1:50 000: arkusz Lubień. Wydawnictwa Geologiczne, Warszawa.

Klatkowa H., 1972. Paleogeografia Wyżyny Łódzkiej i obszarów sąsiednich podczas zlodowacenia warciańskiego. Acta Geographica Lodziensia, 28, Łódzkie Towarzystwo Naukowe, Łódź.

Kobyłecki M., 1948. Kredowa niecka tomaszowska. Biuletyn - Państwowy Instytut Geologiczny, 41, 52-63.

Kondracki J., 2011. Geografia regionalna Polski. Wydawnictwo Naukowe PWN, Warszawa.

Krysiak S., 1999. Typy geokompleksów i kierunki ich użytkowania w środkowej części dorzecza Pilicy. Acta Geographica Lodziensia, 75, Łódzkie Towarzystwo Naukowe, Łódź.

Krzemiński T., 1988. Quaternary stratigraphy of the interfluve between the Warta and Widawka Rivers. Quaternary Studies in Poland, 8, 27-55.

Krzemiński T., 1989. Powiązania form dolinnych środkowej Polski z obiegiem wody w małych zlewniach. [in:] Klatkowa H. (red.), Zagadnienia rozwoju sieci dolinnej w Środkowej Polsce, Acta Geographica Lodziensia, 59, Łódzkie Towarzystwo Naukowe, Łódź, 95-119.

Krzemiński T., 1997. Cechy rozwoju i zaniku lądolodu warciańskiego w środkowej Polsce. Acta Universitatis Lodziensis. Folia Geographica Physica, 1, 47-55.

Krzyszkowski D., 1992. Czwartorzęd rowu Kleszczowa: litostratygrafia i tektonika: zarys problematyki na podstawie obserwacji w odkrywce KWB „Bełchatów”. Studia Geograficzne, 54, Acta Universitatis Wratislaviensis, 1252, Wydawnictwo Uniwersytetu Wrocławskiego, Wrocław.

Kurkowski S. \& Popielski W., 1991. Objaśnienia do Szczegółowej mapy geologicznej Polski w skali 1:50 000: arkusz Gorzkowice. Wydawnictwa Geologiczne, Warszawa.

Kwapisz B., 1983. Objaśnienia do Szczegółowej mapy geologicznej Polski w skali 1:50 000: arkusz Przedbórz. Wydawnictwa Geologiczne, Warszawa.

Lewiński I., 1928. Utwory peryglacjalne i glacjalne Piotrkowa i okolic. Sprawozdania z Posiedzeń Towarzystwa Naukowego Warszawskiego, 21, 82-105.

Lambeck K., Purcell A., Funder S., Kjær K., Larsen E. \& Möller P., 2006. Constrains on the Saalian to Early Middle Weischelian ice sheet of Eurasia from field data and rebound modeling. Boreas, 35, 539-575.

Lindner L., 1970. Glacjalne tarasy marginalne lądolodu zlodowacenia środkowopolskiego na północno-zachodnim obrzeżeniu Gór Świętokrzyskich. Acta Geologica Polonica, 20, 3, 635-645.

Lindner L., 1971. Stratygrafia plejstocenu i paleomorfologia północno-zachodniego obrzeżenia Gór Świętokrzyskich. Studia Geologica Polonica, 35, Wydawnictwa Geologiczne, Warszawa.

Lindner L., 1977. Zlodowacenie plejstoceńskie w zachodniej części Gór Świętokrzyskich. Studia Geologica Polonica, 53, Wydawnictwa Geologiczne, Warszawa.

Lindner L., Marks L. \& Nita M., 2013. Climatostratigraphy of interglacials in Poland: Middle and Upper Pleistocene lower boundaries from a Polish perspective. Quaternary International, 292, 113-123.

Łuniewski A., 1947. Z geologii okolic Radomska i cztery głębokie wiercenia na Kujawach: wydanie pośmiertne prac ze wspomnieniem. Biuletyn - Państwowy Instytut Geologiczny, 38, 1-48.

Manikowska B., 2000. Trzeciorzędowe i plejstoceńskie elementy profilu wietrzeniowego Góry Chełmo koło Przedborza. [in:] Turkowska K. (red.), Przykłady badań geomorfologicznych $w$ regionie łódzkim, Acta Geographica Lodziensia, 78, Łódzkie Towarzystwo Naukowe, Łódź, 43-71.

Passendorfer E., 1927. Sprawozdanie z badań terenowych wykonanych w 1926 r. na arkuszu Przedbórz. Posiedzenia Naukowe Państwowego Instytutu Geologicznego, 16, 10-12.

Pożaryski W., 1971. Tektonika elewacji radomskowskiej. Rocznik Polskiego Towarzystwa Geologicznego, 41, 1, 169-179.

Pożaryski W. \& Brochwicz-Lewiński W., 1979. O aulakogenie środkowopolskim. Kwartalnik Geologiczny, 23, 2, 271-289.

Rdzany Z., 2009. Rekonstrukcja przebiegu zlodowacenia Warty $w$ regionie łódzkim. Wydawnictwo Uniwersytetu Łódzkiego, Łódź.

Różycki S.Z., 1972. Plejstocen Polski środkowej na tle przeszłości w górnym trzeciorzędzie. Państwowe Wydawnictwo Naukowe, Warszawa.

Ruszczyńska-Szenajch H., 1966. Stratygrafia plejstocenu i paleomorfologia rejonu dolnej Pilicy. Studia Geologica Polonica, 22, Wydawnictwa Geologiczne, Warszawa.

Samsonowicz J., 1937. Sprawozdanie z badań geologicznych nakrawędzinieckikredowejłódzkiej. Posiedzenia Naukowe Państwowego Instytutu Geologicznego, 48, 241-242.

Sobolewska M., 1952. Interglacjał w Barkowicach Mokrych pod Sulejowem. [in:] Biuletyn - Państwowy Instytut Geologiczny, 66 (Z badań czwartorzędu w Polsce. T. 2), 245-284.

Solon J., Borzyszkowski J., Bidłasik M., Richling A., Badora K., Balon J., Brzezińska-Wójcik T., Chabudziński Ł., Dobrowolski R., Grzegorczyk I., Jodłowski M., Kistowski M., Kot R., Krąż P., Lechnio J., Macias A., Majchrowska A., Malinowska E., Migoń P., Myga-Piątek U., Nita J., Papińska E., Rodzik J., Strzyż M., Terpiłowski S. \& Ziaja W., 2018. Physico-geographical mesoregions of Poland: Verification and adjustment of boundaries on the basis of contemporary spatial data. Geographia Polonica, 91, 2, 143-170.

Stupnicka E., 1989. Geologia regionalna Polski. Wydawnictwa Geologiczne, Warszawa. 
Stupnicka E. \& Stempień-Sałek M., 2016. Geologia regionalna Polski. Wydawnictwa Uniwersytetu Warszawskiego, Warszawa.

Tokarski A., 1958. O typach struktur wału metakarpackiego. Kwartalnik Geologiczny, 2, 4, 807-824.

Turkowska K., 2006. Geomorfologia regionu łódzkiego. Wydawnictwo Uniwersytetu Łódzkiego, Łódź.

Wachecka-Kotkowska L., 2004. Ewolucja doliny Luciąży: uwarunkowania lokalne i klimatyczne. Acta Geographica Lodziensia, 86, Łódzkie Towarzystwo Naukowe Łódź.

Wachecka-Kotkowska L., 2006. Relacje między ukształtowaniem współczesnej powierzchni Równiny Piotrkowskiej i Wzgórz Radomszczańskich z planem strukturalnym podłoża. [in:] Czubla P. \& Mizerski W. (red.), Geologia regionu łódzkiego i obszarów sąsiednich. Przeszłość dla przyszłości, Wydawnictwo Uniwersytetu Łódzkiego, Łódź, 33-46.

Wachecka-Kotkowska L., 2013. Budowa geologiczna form glacimarginalnych na Wyżynie Przedborskiej - studia przykładowe. Biuletyn Państwowego Instytutu Geologicznego, 454, 103-120.
Wachecka-Kotkowska L., 2015a. Rozwój rzeźby obszaru między Piotrkowem Trybunalskim, Radomskiem a Przedborzem $w$ czwartorzędzie. Wydawnictwo Uniwersytetu Łódzkiego, Łódź.

Wachecka-Kotkowska L., 2015b. Badania ułożenia klastów w glinach morenowych jako element rekonstrukcji kierunków transportu lodowego w obszarze między Piotrkowem Trybunalskim, Radomskiem a Przedborzem. [in:] Turkowska K. (red.), Strefa marginalna lądolodu warty w środkowej $i$ wschodniej Polsce, Acta Geographica Lodziensia, 103, Łódzkie Towarzystwo Naukowe, Łódź, 99-111. Wągrowski A., 1987. Objaśnienia do Szczegółowej mapy geologicznej Polski w skali 1:50 000: arkusz Rzejowice. Wydawnictwa Geologiczne, Warszawa.

Ziomek J., 1986. Objaśnienia do Szczegółowej mapy geologicznej Polski w skali 1: 50 000: arkusz Piotrków Trybunalski. Wydawnictwa Geologiczne, Warszawa.

Żelaźniewicz A., Aleksandrowski P., Buła Z., Konon A., Oszczypko N., Ślączka A., Żaba J. \& Żytko K., 2011. Regionalizacja tektoniczna Polski. Komitet Nauk Geologicznych PAN, Wrocław. 